\title{
INFLuence OF WheAT STRAW AND RHIZOSPHERE ON SEed Germination, Early Seedling Growth and Bio-Chemical ATTRIBUTES OF Trianthema portulacastrum ${ }^{1}$
}

\author{
Influência de Palha de Trigo e Rizosfera sobre a Germinação de Sementes, Crescimento Precoce \\ das Mudas e Atributos Bioquímicos do Trianthema portulacastrum
}

KHALIQ, A. ${ }^{2}$, MATLOOB, A. ${ }^{2}$, ASLAM, F. ${ }^{2}$ and BISMILLAH KHAN, M. ${ }^{3}$

\begin{abstract}
Decomposing wheat (Triticum aestivum) straw and rhizosphere-infested soil were evaluated for their suppressive activity against horse purslane (Trianthema portulacastrum), a noxious summer weed in Pakistan. Two separate pot studies were carried out. Wheat straw was incorporated at 4, 6 and $8 \mathrm{~g} \mathrm{~kg}^{-1}$ soil five days before the sowing of horse purslane. Pots without straw incorporation were maintained as control. In a second study, soil was taken from 15 and $30 \mathrm{~cm}$ depths from a previously cropped wheat field immediately after its harvest and was used as growing medium. Soil from an intentionally uncropped area of the same field was used as control. Suppressive activity was measured in terms of germination dynamics, seedling growth, and biochemical attributes such as chlorophyll contents, total soluble phenolics, soluble protein and antioxidant enzymes. Germination, seedling growth, chlorophyll contents and soluble protein of horse purslane were all negatively influenced. Higher phenolics and enhanced activities of antioxidant enzymes were noticed in response to wheat residues incorporation and its rhizosphere soil. Both studies established that the phytotoxic influence of wheat straw and wheat-infested rhizosphere soil on horse purslane can further be exploited for horse purslane management as a sustainable approach.
\end{abstract}

Keywords: allelopathic rhizosphere, chlorophyll, phenolics, antioxidants.

\begin{abstract}
RESUMO - Restos culturais de trigo (Triticum aestivum) em decomposição e o solo da rizosfera foram avaliados quanto à supressão da atividade contra Trianthema portulacastrum, uma planta daninha de verão comum no Paquistão. Dois estudos independentes foram realizados em vasos. Palha de trigo foi incorporada ao solo em taxas de 4, 6 e $8 \mathrm{~g} \mathrm{~kg}^{-1}$, cinco dias antes da semeadura de $\boldsymbol{P}$. trianthema. Vasos sem incorporação de palha foram mantidas como testemunha. No segundo estudo, o solo foi coletado das profundidades de 15 e $30 \mathrm{~cm}$ de profundidade de um campo recentemente cultivado com trigo imediatamente após a sua colheita e foi usado como meio de cultura. Solo de uma área intencionalmente não cultivada do mesmo campo foi utilizado como controle. A atividade supressora foi medida em termos de dinâmica de germinação, crescimento de plântulas, e atributos bioquimicos como o conteúdo de clorofila, fenólicos totais solúveis, proteínas solúveis e enzimas antioxidantes. Germinação, crescimento, teores de clorofila e proteina solúvel de $\boldsymbol{P}$. trianthema foram todos influenciados negativamente. Teores mais altos de fenólicos e maiores atividades de enzimas antioxidantes foram observadas em resposta à incorporação de residuos de trigo e seu solo rizosférico. Ambos os estudos estabeleceram influência fitotóxica de palha de trigo e do solo da rizosfera de trigo sobre $\boldsymbol{P}$. trianthema, o que pode ser explorado no futuro para o manejo desta espécie com uma abordagem sustentável.
\end{abstract}

Palavras-chave: alelopatia, clorofila, fenólicos, antioxidantes.

1 Recebido para publicação em 23.2.2011 e aprovado em 25.4.2011.

2 Department of Agronomy, University of Agriculture, Faisalabad, Pakistan, <khaliquaf@gmail.com>. ${ }^{3}$ Department of Agronomy, University College of Agriculture, B.Z.U, Multan, Pakistan. 


\section{INTRODUCTION}

Modern agriculture is productivity oriented and relies predominantly on synthetic inputs to tackle weeds and other pest problems. The intensive herbicide use for controlling weeds over last few decades is posing serious ecological and environmental threats to planet and its inhabitants. Herbicide residues in products and their accumulation in soil and ground water, changes in weed populations, evolution of resistant weed biotypes and associated health hazards have diverted the research attention to discover and establish alternative weed management strategies.

Allelopathy, an important ecological phenomenon explaining the interference among species through bio-chemical pathways, seems to be one such tool that can be manipulated to manage weeds in agro-ecosystems (Khanh et al., 2005). The utilization of allelopathic properties of native plant/crop species offers promising opportunities for this purpose. Allelopathic effects are manifested in the form of retarded germination and impaired seedling growth of receiver species which are in turn a secondary expression of malfunctioning of metabolic events, damage to cellular compartments and disruption of physiological processes. Allelochemicals can interfere with basic processes of receiver plants as photosynthesis, cell division, respiration and protein synthesis (Duke \& Dayan, 2006) and indirectly provoke other forms of stresses. Another important effect of these allelochemicals is the activation of cellular antioxidant system in response to uncontrolled production and accumulation of reactive oxygen species (Bogatek \& Gniazdowska, 2007). Thus, allelopathy can also indirectly trigger a cross-stress, most possibly an oxidative burst.

Allelopathic plant residues on decomposition are reported to produce a variety of phytotoxins in the soil causing adverse effects on the other plants (Nelson, 1996), and have potential to cater chemical as well as physical effects on the growth and development of neighboring crop and weed species (Reddy, 2001). Such residues can be exploited for weed suppression, and thus can be helpful in reducing reliance on herbicides
(Weston, 1996). Such an approach can also help to bring down the undesirable effects of current agricultural practices and the cost of high energy inputs in agro-ecosystems (Singh et al., 2003).

Wheat (Triticum aestivum) has been extensively studied for its allelopathic potential. The allelopathic activity of wheat has been attributed to hydroxamic acids and related compounds (Blum et al., 1991; Wu et al., 2000a) and phenolic acids (Copaja et al., 1999; Wu et al., 2001). Wheat seedlings, straw, aqueous extracts of residues and root exudates exerted allelopathic effects on a number of agricultural weeds (Steinsiek et al., 1982; Shilling et al., 1985; Muminovic, 1991; Wu et al., 2000a, b). Wheat is the main winter crop grown throughout Pakistan. In rotation, it is followed by maize, rice and cotton as summer crops. Horse purslane (Trianthema portulacastrum) is a predominant weed in almost all of these summer crops. Decomposing straw and stubbles of wheat are supposed to release phytotoxins in the rhizosphere that might suppress the germination of the weeds and/or the succeeding crop. Present study aims at investigating the allelopathic potential of decomposing wheat straw and its rhizosphere infested soil on the germination, early seedling growth and its biochemical attributes of horse purslane.

\section{MATERIAL AND METHODS}

\section{Bioassays studies}

Horse purslane seeds were collected and cleaned manually to ensure physical purity. These seeds were surface sterilized with water: bleach solution (10:1) for 15 minutes and rinsed with distilled water four times. Plastic pots measuring $29 \times 18 \mathrm{~cm}(10 \mathrm{~kg})$ were filled with air dried and well mixed field soil collected from the Agronomic Research Area. Soil belongs to the Lyallpur soil series (Aridisol-fine-silty, mixed, hyperthermic Ustalfic, Haplargid in USDA classification, and Haplic Yermosols in FAO's classification scheme). The $\mathrm{pH}$ of saturated soil paste and electrical conductivity of the saturation extract were 7.6 and $0.79 \mathrm{dS} \mathrm{m}^{-1}$, respectively. The soil was sandy clay loam with sand, silt and clay 
in proportion of $48.20,23.47$ and $28.33 \%$, respectively. Twenty horse purslane seeds were sown in each pot. The pots were placed in a screen house under natural conditions with a 14/10 h light/dark photoperiod. Pots were irrigated as and when required to avoid water stress.

Germination counts were recorded on a daily basis according to AOSA (1990) until a constant count was achieved. Seeds were considered to be germinated when the radicle and hypocotyl length was over $2 \mathrm{~mm}$. The time taken to $50 \%$ emergence of seedlings $\left(E_{50}\right)$ was calculated according to the modified formulae of Farooq et al., (2005).

$$
\mathrm{E}_{50}=\mathrm{t}_{\mathrm{i}}+\frac{\left(\frac{\mathrm{N}}{2}-\mathrm{n}_{\mathrm{i}}\right)\left(\mathrm{t}_{\mathrm{j}}-\mathrm{t}_{\mathrm{i}}\right)}{\mathrm{n}_{\mathrm{j}}-\mathrm{n}_{\mathrm{i}}}
$$

where, $\mathrm{N}$ is the final number of emerged seeds, and $n_{i}$ and $n_{j}$ are the cumulative number of seeds emerged by adjacent counts at times $t_{i}$ and $t_{j}$ where $n_{i}<N / 2<n_{j}$. Mean emergence time (MET) was calculated according to Ellis \& Robert (1981):

$$
\text { MET }=\frac{\sum \text { Dn }}{\sum n}
$$

where, $\mathrm{n}$ is the number of seeds, which were emerged on day $\mathrm{D}$, and $\mathrm{D}$ is the number of days counted from the beginning of emergence. Emergence Index (EI) was calculated as described by AOSA (1983):

$$
\begin{aligned}
\text { EI } & =\frac{\text { No.of emerged seeds }}{\text { Days of first count }}+----- \\
& +\frac{\text { No.of emerged seeds }}{\text { Days of final count }}
\end{aligned}
$$

Root and shoot lengths were measured 21 days after sowing with a measuring tape. All roots and shoots from each pot were cut separately and oven dried at $70{ }^{\circ} \mathrm{C}$ for $48 \mathrm{~h}$ to get dry biomass of root and shoot; total seedling biomass of seedling was calculated as the sum of the biomass of root and shoot. The number of leaves, lateral branches, nodes and secondary roots were counted manually and averaged. A sub-sample of $2 \mathrm{~g}$ leaves was used to measure the leaf area using a Leaf Area Mater (Licor, Model LI-3000).

\section{Experiment-I: Incorporation of wheat straw for germination and seedling suppression of horse purslane}

Whole-wheat straw residue was evaluated to establish germination and growth inhibition of horse purslane. Wheat straw ( $c v$. Sehar-2006) was collected from crop harvested during the 2008-09 growing season and dried under shade. The straw was chopped with an electric fodder cutter into about $2-3 \mathrm{~cm}$ pieces. Chopped wheat straw was mixed into the soil in situ at 4,6 and $8 \mathrm{~g} \mathrm{~kg}^{-1}$ of soil $\left(8,12,16 \mathrm{t} \mathrm{ha}^{-1}\right.$, respectively). Control treatment contained bare soil. Seeds of horse purslane were sown after 5 days of straw incorporation.

\section{Experiment-II: Wheat-infested rhizosphere soil for germination and seedling suppression of horse purslane}

The allelopathic effects of preceding wheat crop were studied by growing horse purslane in wheat infested rhizosphere soil from depths of $15 \mathrm{~cm}$ (top) and $30 \mathrm{~cm}$ (sub-soil). Soil was taken from the field that was previously cropped with wheat. Soil was also collected from an intentionally un-cropped area of same field to be used as control treatment. Ten soil samples were taken from each depth and mixed thoroughly to achieve homogeneity. Mixed soil was used as a growing medium for the sowing of twenty horse purslane seeds in each pot.

\section{Wheat infested rhizosphere soil analyses}

Soil to be used in this experiment was collected from respective depths and field, air-dried, sieved and stored in paper bags. The same soil was analyzed for various physical-chemical properties in an effort to separate allelopathic interference from resource competition. The $\mathrm{pHs}$ of saturated soil paste and electrical conductivity of the saturation extract were determined with the help of digital $\mathrm{pH}$ and conductivity meter (HI-9811, Hannah, USA). Organic matter was determined by rapid titration method 
(Walkley \& Black, 1934). Total water-soluble phenolic contents were determined as per Swain \& Hillis (1959) using Folin-cicalteu reagent and are expressed as ferullic acid equivalents. Available nitrogen (Kjeldahl's method), available phosphorus (molybdenum blue method) and potassium (ammonium acetate extract, $\mathrm{pH} 7$ ) were measured as per Allen (1989).

\section{Biochemical analyses}

Total soluble phenolics were determined as described by Randhir \& Shetty (2005) and are expressed as gallic acid equivalents. Photosynthetic pigments (Chl.a and Chl.b) were extracted in $80 \%$ ice cold acetone and read out at 663 and $645 \mathrm{~nm}$ wavelength in a UV-spectrophotometer (UV-4000, ORI, Germany). These are expressed as $\mathrm{mg} \mathrm{g}^{-1}$ fresh leaf weight (Lichtenthaler, 1987). Soluble proteins were measured as per Bradford (1976) using crystalline bovine albumin as a reference. Superoxide dismutase (SOD) activity was calculated as described by Giannopotitis \& Ries (1977) at $560 \mathrm{~nm}$. One unit of SOD activity was defined as the amount of enzyme inhibiting the photochemical reduction of NBT by $50 \%$ per minute. Catalase (CAT) activity based on the consumption of $\mathrm{H}_{2} \mathrm{O}_{2}$ was determined using the method of Dhindsa et al., (1981). The consumption of $\mathrm{H}_{2} \mathrm{O}_{2}$ was observed at $240 \mathrm{~nm}$ and one unit of CAT was defined as the amount of enzyme required to oxidize $1 \mu \mathrm{M} \mathrm{H}_{2} \mathrm{O}_{2} \mathrm{~min}^{-1}$. Peroxidase (POX) activity was recorded as described by Egley et al. (1983). The increase in absorbance due to guaiacol oxidation was measured at $470 \mathrm{~nm}$. One unit of enzyme activity was defined as the amount of enzyme required to oxidize $1 \mu \mathrm{M}$ guaiacol $\mathrm{min}^{-1}$.

\section{Experimental design and statistical analysis}

All the experiments were conducted using a completely randomized design with five replications. Following a Fisher's analysis of variance technique (Steel et al., 1997), mean values were separated using least significant differences (LSD) at $p<0.05$ using the computer statistical program MSTAT-C (Freed \& Scott, 1986).

\section{RESULTS AND DISCUSSION}

\section{Experiment-I: Incorporation of wheat straw for germination and seedling suppression of horse purslane}

The incorporation of wheat straw delayed germination of horse purslane by about one to one and a half day, while the time taken to $50 \%$ emergence also varied amongst the treatments (Table 1). The final germination of this weed was suppressed by $36.3 \%$ by wheat straw incorporation. Mean germination time remained non-significant, while significantly lower emergence index of horse purslane over control was recorded for different levels of straw used in present studies (Table 1).

According to the data in Table 2, the incorporation of wheat straw at various rates exerted phytotoxic effects on seedling growth of horse purslane that increased with the quantity of incorporated wheat straw. Shoot and root length of horse purslane were reduced to similar extent by wheat straw over control and maximum reduction (60 and 46\%) was recorded with wheat straw incorporated at 6 and $8 \mathrm{~g} \mathrm{~kg}^{-1}$ of soil respectively. Highest suppression (65 and 64\%) in shoot and root dry weight was associated with wheat straw incorporated at $8 \mathrm{~g} \mathrm{~kg}^{-1}$ of soil.

Total chlorophyll content in horse purslane leaves declined with increasing rate of wheat straw incorporation and 40, 45 and $65 \%$ reduction over control was recorded for wheat straw used at 4,6 and $8 \mathrm{~g} \mathrm{~kg}^{-1}$ of soil (Table 3). Horse purslane seedling developing under increasing stress of wheat residue phytotoxicity recorded increasing levels of water soluble phenolics (Table 3). Wheat straw incorporation at 4, 6 and $8 \mathrm{~g} \mathrm{~kg}^{-1}$ of soil showed an increase of 18,30 and $47 \%$ increase in total soluble phenolics over control. Soluble protein in seedling of horse purslane decreased, but the difference over control (51\%) was significant only for wheat straw used at $8 \mathrm{~g} \mathrm{~kg}^{-1}$ of soil. Higher CAT and POX activity was associated with the incorporation of wheat straw as compared with control (Table 3), and the increasing levels of straw were more stimulatory to such an activity. Albeit an increase in its activity $(70 \%)$ at lower straw incorporation rate $\left(4 \mathrm{~g} \mathrm{~kg}^{-1}\right.$ of soil), the SOD 
activity exhibited a decline ( 7 and $16 \%$ ) at higher straw rates tested, possibly due to failure of this antioxidant to cope with oxidative stress.

Table 1 - Effect of wheat straw on germination traits of horse purslane

\begin{tabular}{|c|c|c|c|c|c|}
\hline Treatment & $\begin{array}{l}\text { Time to start } \\
\text { germination } \\
\text { (days) }\end{array}$ & $\begin{array}{c}\text { Final } \\
\text { germination } \\
\text { percentage }\end{array}$ & $\begin{array}{c}\text { Time to } 50 \% \\
\text { emergence } \\
\text { (days) }\end{array}$ & $\begin{array}{c}\text { Mean } \\
\text { germination } \\
\text { time }\end{array}$ & $\begin{array}{c}\text { Emergence } \\
\text { Index }\end{array}$ \\
\hline Control & $5.00 \mathrm{~b}$ & $76.67 \mathrm{a}$ & $7.37 \mathrm{ab}$ & $9.62^{\text {N.S }}$ & $7.72 \mathrm{a}$ \\
\hline Wheat straw at $4 \mathrm{~g} \mathrm{~kg}^{-1}$ soil & $\begin{array}{c}6.33 \mathrm{ab} \\
(27)\end{array}$ & $\begin{array}{c}55.00 \mathrm{~b} \\
(-29)\end{array}$ & $\begin{array}{c}7.93 \mathrm{a} \\
(8)\end{array}$ & $\begin{array}{l}9.29 \\
(-3)\end{array}$ & $\begin{array}{c}4.34 \mathrm{ab} \\
(-44)\end{array}$ \\
\hline Wheat straw at $6 \mathrm{~g} \mathrm{~kg}^{-1}$ soil & $\begin{array}{c}6.00 \mathrm{ab} \\
(20)\end{array}$ & $\begin{array}{c}45.00 b \\
(-41)\end{array}$ & $\begin{array}{c}7.00 \mathrm{~b} \\
(-5)\end{array}$ & $\begin{array}{l}9.38 \\
(-2)\end{array}$ & $\begin{array}{c}4.21 \mathrm{~b} \\
(-45)\end{array}$ \\
\hline Wheat straw at $8 \mathrm{~g} \mathrm{~kg}^{-1}$ soil & $\begin{array}{c}6.67 \mathrm{a} \\
(33)\end{array}$ & $\begin{array}{c}46.67 \mathrm{~b} \\
(-39)\end{array}$ & $\begin{array}{l}7.33 \mathrm{ab} \\
(-0.54)\end{array}$ & $\begin{array}{c}11.25 \\
(17)\end{array}$ & $\begin{array}{c}5.58 \mathrm{ab} \\
(-28)\end{array}$ \\
\hline LSD & 1.54 & 13.86 & 0.89 & - & 3.42 \\
\hline
\end{tabular}

Means with different letters differ significantly at $5 \%$ probability level by LSD test. Numbers in parenthesis show percent change over control.

Table 2 - Effect of wheat straw on early seedling growth of horse purslane

\begin{tabular}{|c|c|c|c|c|c|c|c|c|c|c|}
\hline Treatment & $\begin{array}{l}\text { Shoot } \\
\text { length } \\
(\mathrm{cm})\end{array}$ & $\begin{array}{l}\text { Root } \\
\text { length } \\
(\mathrm{cm})\end{array}$ & $\begin{array}{l}\text { Shoot dry } \\
\text { weight (g } \\
\left.\text { seedling }{ }^{-1}\right)\end{array}$ & $\begin{array}{l}\text { Root dry } \\
\text { weight (g } \\
\left.\text { seedling }^{-1}\right)\end{array}$ & \begin{tabular}{|l} 
Total dry \\
weight (g \\
seedling $\left.^{-1}\right)$
\end{tabular} & \begin{tabular}{|c|} 
Leaf score \\
per plant
\end{tabular} & $\begin{array}{c}\text { Secondary } \\
\text { roots per } \\
\text { plant }\end{array}$ & $\begin{array}{c}\text { Nodes per } \\
\text { plant }\end{array}$ & \begin{tabular}{|c} 
Lateral \\
shoots per \\
plant
\end{tabular} & $\begin{array}{c}\text { Leaf area } \\
\left(\mathrm{cm}^{2}\right)\end{array}$ \\
\hline Control & $26.53 \mathrm{a}$ & $15.41 \mathrm{a}$ & $3.87 \mathrm{a}$ & $0.22 \mathrm{a}$ & $4.08 \mathrm{a}$ & $20.11 \mathrm{a}$ & $4.75 \mathrm{a}$ & & $9.30 \mathrm{a}$ & $140.07 \mathrm{a}$ \\
\hline Wheat straw at $4 \mathrm{~g} \mathrm{~kg}^{-1}$ soil & $\begin{array}{c}16.77 \mathrm{~b} \\
(-37)\end{array}$ & $\begin{array}{c}12.03 \mathrm{~b} \\
(-22)\end{array}$ & $\begin{array}{c}2.67 b \\
(-31)\end{array}$ & $\begin{array}{c}0.16 \mathrm{ab} \\
(-27)\end{array}$ & $\begin{array}{c}2.83 \mathrm{~b} \\
(-31)\end{array}$ & $\begin{array}{c}11.55 \mathrm{~b} \\
(-43)\end{array}$ & $\begin{array}{c}3.22 \mathrm{~b} \\
(-32)\end{array}$ & $\begin{array}{l}9.62 \mathrm{~b} \\
(-40)\end{array}$ & $\begin{array}{l}5.61 b \\
(-40)\end{array}$ & $\begin{array}{c}130.43 \mathrm{~b} \\
(-7)\end{array}$ \\
\hline Wheat straw at $6 \mathrm{~g} \mathrm{~kg}^{-1}$ soil & $\begin{array}{c}10.79 \mathrm{c} \\
(-59)\end{array}$ & $\begin{array}{l}8.46 \mathrm{c} \\
(-45)\end{array}$ & $\begin{array}{c}1.99 \mathrm{bc} \\
(-49)\end{array}$ & $\begin{array}{c}0.12 \mathrm{bc} \\
(-45)\end{array}$ & $\begin{array}{c}2.12 b c \\
(-48)\end{array}$ & $\begin{array}{c}11.33 \mathrm{~b} \\
(-44)\end{array}$ & $\begin{array}{c}2.87 \mathrm{bc} \\
(-40)\end{array}$ & $\begin{array}{c}9.56 \mathrm{~b} \\
(-40)\end{array}$ & $\begin{array}{c}4.34 \mathrm{~b} \\
(-53)\end{array}$ & $\begin{array}{c}127.14 \mathrm{~b} \\
(-9)\end{array}$ \\
\hline Wheat straw at $8 \mathrm{~g} \mathrm{~kg}^{-1}$ soil & $\begin{array}{c}10.28 \mathrm{c} \\
(-61)\end{array}$ & $\begin{array}{l}8.10 \mathrm{c} \\
(-47)\end{array}$ & $\begin{array}{l}1.37 \mathrm{c} \\
(-65)\end{array}$ & $\begin{array}{l}0.08 \mathrm{c} \\
(-64)\end{array}$ & $\begin{array}{l}1.45 \mathrm{c} \\
(-64)\end{array}$ & $\begin{array}{l}6.34 \mathrm{c} \\
(-68)\end{array}$ & $\begin{array}{l}2.22 \mathrm{c} \\
(-53)\end{array}$ & $\begin{array}{l}4.58 \mathrm{c} \\
(-71)\end{array}$ & $\begin{array}{c}2.38 \mathrm{c} \\
(-74)\end{array}$ & $\begin{array}{c}118.00 \mathrm{c} \\
(-16)\end{array}$ \\
\hline LSD & 3.18 & 2.64 & 1.01 & 0.08 & 1.12 & 1.37 & 0.75 & 1.87 & 1.58 & 6.67 \\
\hline
\end{tabular}

Means with different letters differ significantly at $5 \%$ probability level by LSD test. Numbers in parenthesis show percent change over control.

Table 3 - Effect of wheat straw on chlorophyll, phenolic contents, soluble proteins and antioxidants of horse purslane

\begin{tabular}{|c|c|c|c|c|c|c|c|c|}
\hline \multirow[b]{2}{*}{ Treatment } & \multicolumn{3}{|c|}{ Pigments ( $\mathrm{mg} \mathrm{g}^{-1}$ fresh weight) } & \multirow{2}{*}{$\begin{array}{l}\text { Total soluble } \\
\text { phenolics } \\
\left(\mathrm{mg} \mathrm{g}^{-1} \mathrm{FW}\right)\end{array}$} & \multirow{2}{*}{$\begin{array}{c}\text { Soluble } \\
\text { proteins } \\
\left(\mathrm{mg} \mathrm{g}^{-1} \mathrm{FW}\right)\end{array}$} & \multicolumn{3}{|c|}{ Antioxidant enzymes } \\
\hline & $\begin{array}{l}\text { Chlorophyll } \\
\text { "a" }\end{array}$ & $\begin{array}{l}\text { Chlorophyll } \\
\text { "b" }\end{array}$ & $\begin{array}{c}\text { Total } \\
\text { chlorophyll }\end{array}$ & & & $\begin{array}{c}\text { CAT (EU } \\
\left.\mathrm{g}^{-1} \mathrm{FW}\right)\end{array}$ & \begin{tabular}{|c|}
$\mathrm{POX}(\mathrm{EU}$ \\
$\left.\mathrm{g}^{-1} \mathrm{FW}\right)$
\end{tabular} & $\begin{array}{c}\text { SOD (EU } \\
\left.\mathrm{g}^{-1} \mathrm{FW}\right)\end{array}$ \\
\hline Control & $5.24 \mathrm{a}$ & $1.43 \mathrm{a}$ & $6.67 \mathrm{a}$ & $1.55 \mathrm{~d}$ & $1.43 \mathrm{a}$ & $5.13 \mathrm{~d}$ & $1.63 \mathrm{c}$ & $55.86 \mathrm{~b}$ \\
\hline Wheat straw at $4 \mathrm{~g} \mathrm{~kg}^{-1}$ of soil & $\begin{array}{c}2.74 \mathrm{~b} \\
(-48) \\
\end{array}$ & $\begin{array}{c}1.29 \mathrm{a} \\
(-10) \\
\end{array}$ & $\begin{array}{c}4.03 \mathrm{~b} \\
(-40) \\
\end{array}$ & $\begin{array}{c}1.83 \mathrm{c} \\
(-18) \\
\end{array}$ & $\begin{array}{c}1.29 \mathrm{a} \\
(-10)\end{array}$ & $\begin{array}{c}10.58 \mathrm{c} \\
(106)\end{array}$ & $\begin{array}{c}2.26 \mathrm{~b} \\
(39) \\
\end{array}$ & $\begin{array}{c}94.97 \mathrm{a} \\
(70)\end{array}$ \\
\hline Wheat straw at $6 \mathrm{~g} \mathrm{~kg}^{-1}$ of soil & $\begin{array}{c}2.45 b \\
(-53)\end{array}$ & $\begin{array}{c}1.24 \mathrm{a} \\
(-13) \\
\end{array}$ & $\begin{array}{l}3.69 \mathrm{bc} \\
(-45)\end{array}$ & $\begin{array}{c}2.02 \mathrm{~b} \\
(-30)\end{array}$ & $\begin{array}{l}1.24 \mathrm{a} \\
(-13)\end{array}$ & $\begin{array}{c}20.31 \mathrm{~b} \\
(296)\end{array}$ & $\begin{array}{l}5.62 \mathrm{a} \\
(245) \\
\end{array}$ & $\begin{array}{c}65.08 \mathrm{~b} \\
(16)\end{array}$ \\
\hline Wheat straw at $8 \mathrm{~g} \mathrm{~kg}^{-1}$ of soil & $\begin{array}{c}1.62 \mathrm{c} \\
(-69)\end{array}$ & $\begin{array}{c}0.70 \mathrm{~b} \\
(-51)\end{array}$ & $\begin{array}{c}2.32 \mathrm{c} \\
(-65)\end{array}$ & $\begin{array}{c}2.27 \mathrm{a} \\
(-47) \\
\end{array}$ & $\begin{array}{c}0.70 \mathrm{~b} \\
(-51)\end{array}$ & $\begin{array}{c}28.62 \mathrm{a} \\
(458)\end{array}$ & $\begin{array}{l}5.30 \mathrm{a} \\
(225)\end{array}$ & $\begin{array}{l}59.70 \mathrm{~b} \\
(7)\end{array}$ \\
\hline LSD & 0.71 & 0.69 & 1.14 & 0.11 & 0.26 & 1.67 & 0.41 & 10.97 \\
\hline
\end{tabular}

Means with different letters differ significantly at $5 \%$ probability level by LSD test. Numbers in parenthesis show percent change over control. CAT: catalase, POX: peroxidase, SOD: superoxide dismutase. 
Khanh et al., (2005) found that inhibition germination and seedling growth became more pronounced with increasing rate of wheat straw that may be explained by increased concentration of individual allelochemicals or their compound effect Phytotoxic compounds namely phenolics ( $p$-hydroxybenzoic, vanillic, pcoumaric, syringic and ferulic acids - being more frequent, and trans-ferulic and transpcoumaric acids-dominant acids), cyclic hydroxamic acids (alkaloids) and short chain fatty acids are reported in wheat straw (Wu et al., 2001; Ma, 2005). Most of these allelochemicals are water soluble and can be imbibed by the germinating weed seeds or can be taken up by roots, thus hampering germination and subsequent seedling growth. This results in an overall decline in the density, vigor and establishment of the weeds (Gallandt et al., 1999). The suppression of germination and seedling growth of horse purslane in present experiments was reflective of the inhibitory effects of wheat straw mediated by the release of above mentioned compounds. Thilsted \& Murray (1980) found that the suppression of Amaranthus spp. in wheat straw-mulched plots was around the one obtained with herbicides in bare-soil plots, while Banks \& Robinson (1980) reported that wheat straw mulch suppressed the growth of spiny amaranth (Amaranthus spinosus), tall morning glory (Ipomoea purpurea) and volunteer wheat even to a greater extent than herbicides. Our results also substantiated previous findings reporting suppression of broad-leaved weeds owing to wheat straw (Shilling et al., 1985; Alsaadawi, 2001; Blum et al., 2002).

\section{Experiment-II: Wheat-infested rhizosphere soil for germination and seedling suppression of horse purslane}

Wheat infested rhizosphere soil from 15 and $30 \mathrm{~cm}$ depth did not influence the time taken to start germination, $50 \%$ emergence and mean germination as compared to the control (Table 4). The final germination percentage of horse purslane was inhibited by $43.5 \%$ when grown in wheat-infestedrhizosphere-soil (Table 4). The emergence index mean of the weed was also depressed by $48 \%$ over control. Soil taken from a higher depth inhibited both germination and emergence index to a lesser extent, albeit both exhibited lower values over control (Table 4).

Soil collected from different depths of wheat field significantly inhibited the seedling growth of horse purslane (Table 5). Soil taken from $15 \mathrm{~cm}$ depth appeared more suppressive than that from $30 \mathrm{~cm}$ depth, being that seedling shoot and root length was suppressed by $29-22$ and $38-25 \%$ by soil from 15 and $30 \mathrm{~cm}$ depth, respectively. Seedling dry weight inhibition of $49.5 \%$ was recorded for rhizosphere soil over control while root dry weight was significantly reduced over control by $50 \%$ with rhizosphere soil only from $15 \mathrm{~cm}$ depth. Leaf score was reduced by $38 \%$ by rhizosphere soil over control. Seedling grown in soil from $15 \mathrm{~cm}$ depth also developed minimum secondary roots, while lateral branches and leaf area were lowest for $30 \mathrm{~cm}$ soil depth (Table 5). Chlorophyll "a" was similar for both soil depths (Table 6), while chlorophyll "b" was reduced by $51 \%$ when determined for soil from $15 \mathrm{~cm}$ depth. Lower total chlorophyll content (29\%) and higher total phenolics (32\%) were observed for soil taken from $15 \mathrm{~cm}$ depth. Wheat infested soil suppressed soluble protein contents in horse purslane by $52 \%$ for soil taken from $30 \mathrm{~cm}$ depth. The activity of CAT was highest when observed for soil from $30 \mathrm{~cm}$ depth while the activity of SOD remained higher for soil from $15 \mathrm{~cm}$ depth (Table 6). Significantly higher phenolic content, lower $\mathrm{pH}, \mathrm{ECe}$ and organic matter over control soil were noted for wheat infested rhizosphere soil (Table 7).

Results of the second experiment suggested that wheat infested rhizosphere soil contained phytotoxic compounds capable of inhibiting germination and early seedling growth of horse purslane (Tables 4, 5). The detection of phenolics in wheat infested soil provided additional insight of quantitative basis of such bio-chemical suppression (Table 7). Total phenolic content of soil from non-till wheat field were significantly higher than that from other systems (Table 7). Most of the phenolic acids appeared to be accumulated in the top $2.5 \mathrm{~cm}$ of the soil and occurred in bound forms in the soil (Blum et al., 1991). Rhizosphere is an active zone where most of the bio-chemical interactions take 
place and it acts as reservoir of most of the active inhibitory compounds that accumulate by root exudation, leaching and/or microbial degradation. Rhizosphere allelochemicals can regulate the biotic communities of soil beside their physical and chemical effects (Sisodia \&
Siddiqui, 2009). Wheat is also a rich source of hydroxamic acids like 2, 4-dihydroxy-(2H)-1, 4benzoxazin-3(4H)-one (DIBOA) and 2, 4dihydroxy-7-methoxy-(2H)-1, 4-benzoxazin$3(4 H)$-one (DIMBOA) (Macias et al., 2004, 2005). These occur as glycosides in plant,

Table 4 - Effect of wheat infested rhizosphere soil depths on germination traits of horse purslane

\begin{tabular}{|l|c|c|c|c|c|}
\hline \multicolumn{1}{|c|}{ Treatment } & $\begin{array}{c}\text { Time to start } \\
\text { germination } \\
\text { (days) }\end{array}$ & $\begin{array}{c}\text { Final } \\
\text { germination } \\
\text { percentage }\end{array}$ & $\begin{array}{c}\text { Time to 50\% } \\
\text { emergence } \\
\text { (days) }\end{array}$ & $\begin{array}{c}\text { Mean } \\
\text { germination } \\
\text { time (days) }\end{array}$ & $\begin{array}{c}\text { Emergence } \\
\text { Index }\end{array}$ \\
\hline Control & $5.00^{\text {N.S }}$ & $88.33 \mathrm{a}$ & $7.72^{\text {N.S }}$ & $8.94^{\text {N.S }}$ & $8.35 \mathrm{a}$ \\
\hline Wheat rhizosphere soil form 0-15 cm depth & $\begin{array}{c}5.33 \\
(7)\end{array}$ & $\begin{array}{c}46.67 \mathrm{~b} \\
(-47)\end{array}$ & $\begin{array}{c}7.11 \\
(-8)\end{array}$ & $\begin{array}{c}8.20 \\
(-8)\end{array}$ & $\begin{array}{c}3.94 \mathrm{~b} \\
(-53)\end{array}$ \\
\hline Wheat rhizosphere soil form 15-30 cm depth & 5.00 & $53.33 \mathrm{~b}$ & 7.22 & 8.57 & $4.78 \mathrm{~b}$ \\
- & $(0.00)$ & $(-40)$ & $(-6)$ & $(-40)$ & $(-43)$ \\
\hline & - & 17.30 & - & - & 3.56 \\
\hline
\end{tabular}

Means with different letters differ significantly at $5 \%$ level of probability, ${ }^{\text {N.S. }}$ Non-significant. Numbers in parenthesis show percent change over control.

Table 5 - Effect of wheat infested rhizosphere soil on early seedling growth in horse purslane

\begin{tabular}{|c|c|c|c|c|c|c|c|c|c|c|}
\hline Treatment & $\begin{array}{l}\text { Shoot } \\
\text { length } \\
(\mathrm{cm})\end{array}$ & $\begin{array}{l}\text { Root } \\
\text { length } \\
(\mathrm{cm})\end{array}$ & $\begin{array}{l}\text { Shoot dry } \\
\text { weight (g } \\
\left.\text { seedling }{ }^{-1}\right)\end{array}$ & $\begin{array}{l}\text { Root dry } \\
\text { weight (g } \\
\left.\text { seedling }{ }^{-1}\right)\end{array}$ & $\begin{array}{c}\text { Total dry } \\
\text { weight }(\mathrm{g} \\
\left.\text { seedling }^{-1}\right)\end{array}$ & $\begin{array}{c}\text { Leaf score } \\
\text { per plant }\end{array}$ & $\begin{array}{c}\text { Secondary } \\
\text { roots per } \\
\text { plant }\end{array}$ & $\begin{array}{c}\text { Nodes per } \\
\text { plant }\end{array}$ & $\begin{array}{l}\text { Lateral } \\
\text { shoots per } \\
\text { plant }\end{array}$ & $\begin{array}{l}\text { Leaf area } \\
\left(\mathrm{cm}^{2}\right)\end{array}$ \\
\hline Control & $23.74 \mathrm{a}$ & $17.28 \mathrm{a}$ & $2.29 \mathrm{a}$ & $0.15 \mathrm{a}$ & $2.44 \mathrm{a}$ & $84.05 \mathrm{a}$ & $14.85 \mathrm{a}$ & $29.39 \mathrm{a}$ & $26.00 \mathrm{a}$ & $146.3 \mathrm{a}$ \\
\hline $\begin{array}{l}\text { Wheat rhizosphere soil } \\
\text { form } 0-15 \mathrm{~cm} \text { depth }\end{array}$ & $\begin{array}{c}16.96 \mathrm{c} \\
(-29) \\
\end{array}$ & $\begin{array}{c}10.67 \mathrm{c} \\
(-38)\end{array}$ & $\begin{array}{c}1.14 \mathrm{~b} \\
(-50) \\
\end{array}$ & $\begin{array}{c}0.08 \mathrm{~b} \\
(-50)\end{array}$ & $\begin{array}{l}1.22 \mathrm{~b} \\
(-50) \\
\end{array}$ & $\begin{array}{c}53.20 \mathrm{~b} \\
(-37) \\
\end{array}$ & $\begin{array}{c}9.27 \mathrm{c} \\
(-38)\end{array}$ & $\begin{array}{c}17.75 \mathrm{~b} \\
(-40)\end{array}$ & $\begin{array}{c}15.71 \mathrm{~b} \\
(-40) \\
\end{array}$ & $\begin{array}{c}137.4 \mathrm{~b} \\
(-6)\end{array}$ \\
\hline $\begin{array}{l}\text { Wheat rhizosphere soil } \\
\text { form } 15-30 \mathrm{~cm} \text { depth }\end{array}$ & $\begin{array}{c}18.57 \mathrm{~b} \\
(-22)\end{array}$ & $\begin{array}{c}13.02 \mathrm{~b} \\
(-25)\end{array}$ & $\begin{array}{l}1.17 \mathrm{~b} \\
(-49)\end{array}$ & $\begin{array}{c}0.09 \mathrm{ab} \\
(-41)\end{array}$ & $\begin{array}{l}1.25 \mathrm{~b} \\
(-49)\end{array}$ & $\begin{array}{c}51.41 \mathrm{~b} \\
(-39)\end{array}$ & $\begin{array}{c}11.69 \mathrm{~b} \\
(-21)\end{array}$ & $\begin{array}{c}15.58 \mathrm{~b} \\
(-47)\end{array}$ & $\begin{array}{c}13.32 \mathrm{c} \\
(-49)\end{array}$ & $\begin{array}{c}127.5 \mathrm{c} \\
(-13)\end{array}$ \\
\hline LSD & 2.97 & 1.37 & 0.28 & 0.06 & 0.35 & 6.29 & 1.44 & 6.43 & 2.30 & 8.64 \\
\hline
\end{tabular}

Means with different letters differ significantly at $5 \%$ level of probability by LSD test. Numbers in parenthesis show percent decrease over control.

Table 6 - Effect of wheat infested rhizosphere soil on chlorophyll, phenolic contents, soluble proteins and antioxidants of horse purslane

\begin{tabular}{|c|c|c|c|c|c|c|c|c|}
\hline \multirow[b]{2}{*}{ Treatment } & \multicolumn{3}{|c|}{ Pigments ( $\mathrm{mg} \mathrm{g}^{-1}$ fresh weight) } & \multirow{2}{*}{$\begin{array}{c}\text { Total } \\
\text { soluble } \\
\text { phenolics } \\
\left(\mathrm{mg} \mathrm{g}^{-1} \mathrm{FW}\right)\end{array}$} & \multirow{2}{*}{$\begin{array}{c}\text { Soluble } \\
\text { proteins } \\
\left(\mathrm{mg} \mathrm{g}^{-1}\right. \\
\text { FW) }\end{array}$} & \multicolumn{3}{|c|}{ Antioxidant enzymes } \\
\hline & $\begin{array}{l}\text { Chlorophyll } \\
\text { "a" }\end{array}$ & $\begin{array}{l}\text { Chlorophyll } \\
\text { "b" }\end{array}$ & $\begin{array}{c}\text { Total } \\
\text { chlorophyll }\end{array}$ & & & $\begin{array}{c}\text { CAT } \\
\left(\mathrm{EU} \mathrm{g}^{-1}\right. \\
\mathrm{FW})\end{array}$ & $\begin{array}{c}\text { POX } \\
\left(\mathrm{EU} \mathrm{g}^{-1}\right. \\
\mathrm{FW})\end{array}$ & $\begin{array}{l}\text { SOD } \\
\left(\mathrm{EU} \mathrm{g}^{-1}\right. \\
\mathrm{FW})\end{array}$ \\
\hline Control & $4.27 \mathrm{a}$ & $2.46 \mathrm{a}$ & $6.73 \mathrm{~b}$ & $1.71 \mathrm{~b}$ & $1.49 \mathrm{a}$ & $9.83 \mathrm{c}$ & $1.78 \mathrm{~b}$ & $40.54 \mathrm{~b}$ \\
\hline $\begin{array}{l}\text { Wheat rhizosphere soil form } \\
0-15 \mathrm{~cm} \text { depth }\end{array}$ & $\begin{array}{c}3.58 \mathrm{a} \\
(-16)\end{array}$ & $\begin{array}{l}1.19 \mathrm{~b} \\
(-51)\end{array}$ & $\begin{array}{l}4.78 \mathrm{a} \\
(-29)\end{array}$ & $\begin{array}{c}2.27 \mathrm{a} \\
(-32)\end{array}$ & $\begin{array}{l}1.22 \mathrm{a} \\
(-18)\end{array}$ & $\begin{array}{c}21.86 \mathrm{~b} \\
(122)\end{array}$ & $\begin{array}{l}5.74 \mathrm{a} \\
(222)\end{array}$ & $\begin{array}{c}76.10 \mathrm{a} \\
(88)\end{array}$ \\
\hline $\begin{array}{l}\text { Wheat rhizosphere soil form } \\
15-30 \mathrm{~cm} \text { depth }\end{array}$ & $\begin{array}{c}4.00 \mathrm{a} \\
(-6)\end{array}$ & $\begin{array}{c}2.09 \mathrm{a} \\
(-15)\end{array}$ & $\begin{array}{l}6.08 \mathrm{a} \\
(-10)\end{array}$ & $\begin{array}{c}2.18 \mathrm{a} \\
(-27)\end{array}$ & $\begin{array}{l}0.72 \mathrm{~b} \\
(-52)\end{array}$ & $\begin{array}{c}30.28 \mathrm{a} \\
(208)\end{array}$ & $\begin{array}{l}6.22 \mathrm{a} \\
(249)\end{array}$ & $\begin{array}{c}44.03 \mathrm{~b} \\
(9)\end{array}$ \\
\hline LSD & 1.56 & 0.87 & 1.65 & 0.30 & 0.33 & 3.65 & 0.53 & 9.28 \\
\hline
\end{tabular}

Means with different letters differ significantly at $5 \%$ probability level by LSD test. Numbers in parenthesis show percent change over control. CAT: catalase, POX: peroxidase, SOD: superoxide dismutase. 
Table 7 - Physical-chemical properties and total water-soluble phenolics of the soil samples

\begin{tabular}{|c|c|c|c|}
\hline \multirow{3}{*}{ Physical-chemical properties } & \multicolumn{3}{|c|}{ Rhizosphere soil } \\
\hline & \multirow{2}{*}{ Uninfested } & \multicolumn{2}{|c|}{ Wheat infested } \\
\hline & & $15 \mathrm{~cm}$ & $30 \mathrm{~cm}$ \\
\hline $\mathrm{pH}$ & 7.6 & 7.5 & 7.5 \\
\hline $\operatorname{ECe}\left(\mathrm{dS} \mathrm{m}^{-1}\right)$ & 0.79 & 0.59 & 0.53 \\
\hline Organic matter $(\%)$ & 0.61 & 0.52 & 0.45 \\
\hline Nitrogen $(\%)$ & 0.062 & 0.058 & 0.040 \\
\hline Phosphorus $\left(\mathrm{mg} \mathrm{kg}^{-1}\right)$ & 15.7 & 15.5 & 14.2 \\
\hline Potassium $\left(\mathrm{mg} \mathrm{kg}^{-1}\right)$ & 184 & 176 & 160 \\
\hline Water-soluble phenolics $\left(\mathrm{mg} \mathrm{kg}^{-1}\right) *$ & 14.4 & 51.2 & 35.4 \\
\hline
\end{tabular}

* Significant difference at 5 and $1 \%$ probability between uninfested and infested soil.

being released as aglycones by the activity of the enzyme $\beta$-glycosidase and are unstable in solution and soil, being transformed to 2benzoxazolinone (BOA), 7-methoxy-2benzoxazolinone (MBOA), and other degradation products. These transformations are dependent on the chemical and biological conditions and some of these transformation products are biologically more active than the original ones (Villagrasa et al., 2009). Soil analyses revealed that phenolics constituted an active portion of phytotoxic compounds of wheat rhizosphere that accounted for horse purslane suppression (Table 7). Lower inorganic ions can be explained by the influence of phenolics on the accumulation of inorganic ions (Inderjit \& Mallik, 1997). Phenolics are known to affect the $\mathrm{pH}$, organic matter and nutrients and are also qualitatively and quantitatively affected by these factors (Inderjit, 1996). Sisodia \& Siddiqui (2009) also noticed growth inhibition of other test species when grown on infested rhizosphere soil of donor allelopathic species.

Chlorophyll content in horse purslane leaves decreased in response to wheat allelopathicity (Tables 3, 6). Wheat allelochemicals might have inhibited chlorophyll in horse purslane by interfering with biosynthesis of photosynthetic pigments or enhancing their degradation by inducing oxidative stress via ROS or through the integration of both (Huang et al., 2010). Reduction in chlorophyll was associated with higher total phenolics in horse purslane seedling (Figure 1). Allelochemical-mediated reduction in seedling photosynthetic pigments primarily due to phenolic acids is also reported by Inderjit \& Dakshini (1992).

Disturbances in germination and alteration in seedling morphology under allelopathic stress in our studies (Tables 1, 2, 4 and 5) have been attributed to induced oxidative damage and the activation of cellular anti-oxidant system (Bogatek \& Gniazdowska, 2007). Oxidative stress can alter permeability and fluxes across plasma membrane causing oxidative burst, enzyme inactivation and root growth and uptake. Plants tend to overcome this situation by activating enzymes of defense systems and increased activity of stress

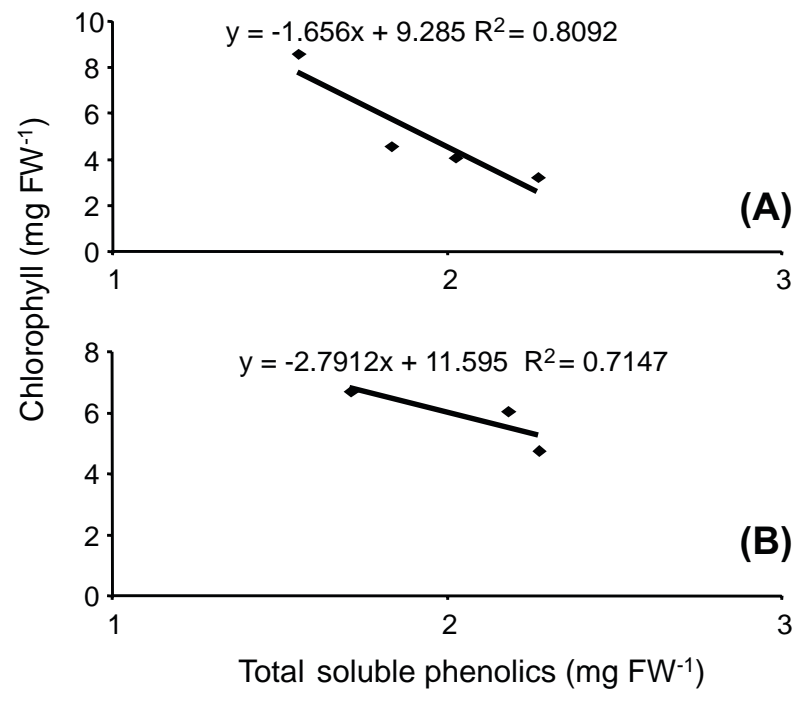

Figure 1 - Relationship between total soluble phenolics and total chlorophyll content in horse purslane treated with (A) wheat straw incorporation and (B) wheat infested rhizosphere soil 
enzymes is regarded as stress marker. SOD, an upstream metalloenzyme is involved in the detoxification of superoxide radicals (Apel \& Hirt, 2004). Decreased activity of SOD at higher straw incorporation rates in present studies indicated the possible failure of antioxidant system to cope with oxidative damage. CAT is an antioxidant that prevents the $\mathrm{H}_{2} \mathrm{O}_{2}$ accumulation in cells while POX also scavenges $\mathrm{H}_{2} \mathrm{O}_{2}$ and protects cell organelles. The increased expression of CAT and POX under allelopathic stress in these experiments is also supported by Niakan \& Mazandrani (2009). Increased POD activity coupled with reduction in root growth strengthens the phenolic acid synthesis by the phenylpropanoid pathway (Ng et al., 2003). The induction and activation of antioxidant system in horse purslane seedlings grown under wheat allelopathy compared with those of control suggested an oxidative nature of damage caused by wheat allelochemicals and at the same time implies that horse purslane possess the ability to activate its antioxidant defense upon exposure to allelopathic or possibly any other stress.

In conclusion, present investigations demonstrated the phytotoxic potential of wheat straw and infested rhizosphere soil against horse purslane germination and seedling growth. Under field conditions, such suppression may vary with the amount of wheat straw available for incorporation at the time of primary tillage for subsequent summer crops, and residual phenolic content of wheat infested rhizosphere soil. Influence of soil and environmental factors on the release and subsequent activity of wheat allelochemicals, and also the root exudates in rhizosphere need to be investigated further. Screening of wheat cultivars of indigenous and exotic origin with greater allelopathic potential and their inclusion into crop rotation is required for developing a natural weed management strategy.

\section{ACKNOWLEDGEMENTS}

The Financial support of Higher Education Commission, Government of Pakistan under National Research Program is highly acknowledged.

\section{LITERATURE CITED}

ALLEN, S. E. Chemical analysis of ecological materials. London, Blackwell Scientific Publishers, 1989. 368 p.

ALSAADAWI, I. S. Allelopathic influence of decomposing wheat residues in agroecosystems. J. Crop Produc., v. 4, n. 2, p. 185-196, 2001.

APEL, K.; HIRT, H. Reactive oxygen species metabolism, oxidative stress, a signal transduction. Ann. Rev. Plant Biol., v. 55, n. 1, p. $373-399,2004$

ASSOCIATION OF OFFICIAL SEED ANALYSIS - ASOA. Seed vigor testing handbook. Springfield: 1983. (Contribution, 32)

ASSOCIATION OF OFFICIAL SEED ANALYSIS - ASOA. Rules for testing seeds. J. Seed Technol., v. 12, n. 3 , p. $1-112,1990$

BANKS, P. A.; ROBINSON, E. L. Effect of straw mulch on pre-emergence herbicides. Proc. South Weed Sci. Soc., v. 33, p. 286,1980 .

BLUM, U. et al. Effect of wheat residues on dicotyledonous weed emergence in a simulated no-till systems. Allelopathy J., v. 9, n. 1, p. 159-176, 2002.

BLUM, U. et al. Phenolic acid content of soils from wheat-no till, wheat-conventional till, and fallow conventional till soybean cropping systems. J. Chem. Ecol., v. 17, n. 6, p. $1045-1068,1991$

BOGATEK, R.; GNIAZDOWSKA, A. ROS and phytohormones in plant-plant allelopathic interactions. Plant Signaling Behavior, v. 2, n. 4, p. 317-318, 2007.

BRADFORD, M. M. A rapid and sensitive method for the quantification of microgram quantities of protein utilizing the principle of protein-dye binding. Analytical biochemistry, v. 72, n. $1-2$, p. $248-254,1976$.

COPAJA, S. V. et al. Accumulation of hydroxamic acids during wheat germination. Phytochemistry, v. 50, n. 1, p. 17-24, 1999

DHINDSA, R. S. et al. Leaf senescence: correlated with increased levels of membrane permeability and lipid peroxidation, and decreased levels of superoxide dismutase and catalase. J. Exper. Bot., v. 32, n. 1, p. 93-101, 1981.

DUKE, S. O.; DYAN, F. E. Mode of action of phytotoxins from plants. In: REIGOSA, M. J.; PEDROL, N.; GONZÁLEZ, L. (Eds.). Allelopathy: a physiological process with ecological implications. Springer, Netherlands. p. 511-536.

Planta Daninha, Viçosa-MG, v. 29, n. 3, p. 523-533, 2011 
EGLEY, G. H. et al. Role of peroxidase in the development of water impermeable seed coats in Sida spinosa L. Planta, v. 157, n. 3 , p. $224-232,1983$.

ELLIS, R. A.; ROBERTS, E. H. The quantification of ageing and survival in orthodox seeds. Seed Sci. Technol., v. 9, p. $373-409,1981$.

FAROOQ, M. et al. Thermal hardening: a new seed vigor enhancing tool in rice. J. Integr. Plant Biol., v. 47, n. 2, p. 187-193, 2005.

FREED, R. D.; SCOTT, D. E. MSTAT-C. Michigan: Crop and Soil Science Dept., Michigan State University, 1986

GALLANDT, E. et al. Improving soil quality: implications for weed management. J. Crop Produc., v. 2, n. 1, p. 95-121, 1999.

GIANNOPOTITIS, C. N.; RIES, S. K. Superoxide dismuatse I. occurrence in higher plants. Plant Physiol., n. 59, v. 2 p. 309-314, 1977.

HUANG, J. H. et al. Allelopathic effects of cassava (Manihot esculenta crantz.) on radish and rye grass (Lolium perene L.). Allelopathy J., v. 25, n. 1, p. 155-162, 2010.

INDERJT, D. Plant phenolics in allelopathy. Bot. Rev., v. 62 , n. 2 , p. $186-202,1996$

INDERJT, D.; MALLIK, A. U. Effects of phenolic compounds on selected soil properties. For. Ecol. Manag., v. 92, n. 1, p. 11-18, 1997.

INDERJT, D.; DAKSHINI, K. M. M. Interference potential of Pluchea lanceolata (Asteraceae): growth and physiological responses of asparagus bean, Vigna unguiculata var. sesquipedalis. Am. J. Bot., v. 79, n. 9, p. 977-981, 1992.

KHANH, T. D. et al. The exploitation of crop allelopathy in sustainable agricultural production. J. Agron.Crop Sci., v. 191, n. 3, p. 172-184, 2005.

LICHTENTHALER, H. K. Chlorophyll and carotenoids: pigments of photosynthetic bio-membranes. In: PACKER, L.; DOUCE, R. (Eds.). Methods in enzymology. San Diego: Academic Press, 1987. p. 350-382.

MA, Y. Q. Allelopathic studies of common wheat (Tritcum aestivum L.). Weed Biol. Manage., v. 5, n. 3, p. 93-104, 2005.

MACIAS, F. A. et al. Degradation studies on benzoxazinoids soil degradation dynamics of 2,4-Dihydroxy-7-methoxy(2H)-1,4-benzoxazin-3(4H)-one (DIMBOA) and its degradation products, phytotoxic allelochemicals from gramineae. J. Agric. Food Chem., v. 52, n. 21, p. 6402-6413, 2004.
MACIAS, F. A. et al. Degradation studies on benzoxazinoids soil degradation dynamics of $(2 R)-2-O-\beta$-D-Glucopyranosyl4-hydroxy-(2H)-1,4-benzoxazin-3(4H)-one (DIBOA-Glc) and its degradation products, phytotoxic allelochemicals from gramineae. J. Agric. Food Chem., v. 53, n. 3, p. 554-561, 2005.

MUMINOVIC, S. Allelopathic influence of straw of crops on the germination, height and weight of weeds. Radovi Poljoprivrednog Fakulteta Univerz. Sarajevu, v. 39, n. 1, p. $29-37,1991$

NELSON, C. J. Allelopathy in cropping systems. Agron. J., v. 88, n. 6 , p. $991-996,1996$.

NG, P. L. L. et al. Canola (Brassica napus L.) seed germination influenced by cinnamic and benzoic acids and derivatives: effects on peroxidase. Seed Sci. Technol., v. 31, n. 1, p. 39-46, 2003

NIAKAN, M.; MAZANDRANI, N. Allelopathic effects of ascorbic acid and canola on germination and antioxidant activity of soybean. Alleopathy J., v. 24, n. 2, p. 283-290, 2009.

RANDHIR, R.; SHETTY, K. Developmental stimulation of total phenolics and related antioxidant activity in light and dark germinated maize by natural elicitors. Process

Biochem., v. 40, n. 5, p. 1721-1732, 2005.

REDDY, K. N. Effect of cereal and legume cover crop residues on weeds, yield and net return in soybean (Glycine max). Weed Technol., v. 15, n. 4, p. 660-668, 2001.

SHILLING, D. G. et al. Rye (Secale cereale L.) and wheat (Triticum aestivum L.) mulch: the suppression of certain broadleaved weeds and the isolation and identification of phytotoxins. In: PUTNAM, A. R.; TANG, C. S. (Eds.). The science of allelopathy. New York, John Wiley \& Sons Inc., 1985. p. 243-271.

SINGH, H. P. et al. Allelopathic interactions and allelochemicals: new possibilities for sustainable weed management. Crit. Rev. Plant Sci., v. 22, n. 3/4, p. 239-311, 2003.

SISODIA, S.; SIDDIQUI, M. B. Allepathic potential of rhizosphere soil of Croton bonplandianum on growth and establishment of some crops and weed plants. Afr. J. Agric. Res., v. 4, n. 5, p. 461-467, 2009.

STEEL, R. G. D. et al. Principles and procedures of statistics: a biometrical approach. 3.ed. New York: McGraw Hill Book, 1997. p. 172-177.

STEINSIEK, J. W. et al. Allelopathic potential of wheat (Triticum aestivum) straw on selected weed species. Weed Sci., v. 30, n. 5, p. 495-497, 1982 
SWAIN, T.; HILLIS, W. E. The phenolic constituents of Prunus domestica $\mathrm{I}$-the quantitative analysis of phenolic constituents. J. Sci. Food Agric., v. 10, n. 1, p. 63-68, 1959.

THILSTED, D. E.; MURRAY, B. S. Effect of wheat straw on weed control in no-tillage soybeans. Proc. South Weed Sci. Soc., v. 33, p. 42, 1980. (Special Edition)

VILLAGRASA, M. et al. Analysis of benzoxazinone derivatives in plant tissues and their degradation products in agricultural soils. TrAC Trends Anal. Chem., v. 28, n. 9, p. $1103-1114,2009$

WALKEY, A.; BLACK, I. A. An examination of the Digtjarett method for determining soil organic matter and a proposed modification of chromic acid titration method. Soil Sci., v. 37, n. 1, p. $28-38,1934$.
WESTON, L. A. Utilization of allelopathy for weed management in agro-ecosystems. Agron. J., v. 88, n. 6, p. 860-866, 1996.

WU, H. et al. Laboratory screening for allelopathic potential of wheat (Triticum aestivum) accessions against annual ryegrass (Lolium rigidum). Austr. J. Agric. Res., v. 51, n. 2, p. $259-266,2000$ b.

WU, H. et al. Allelochemicals in wheat (Triticum aestivum L.) Variation of phenolic acids in shoot tissues. J. Chem. Ecol., v. 27, n. 1 , p. $125-135,2001$.

WU, H. et al. Distribution and exudation of allelochemicals in wheat (Triticum aestivum L.). J. Chem. Ecol., v. 26, n. 9, p. 2141-2154, 2000a. 